\title{
LACZKÓ KRISZTINA
}

\section{A HELYESÍRÁSI HIBÁK ÉRTÉKELÉSE}

\section{Bevezetés}

Bozsik Gabriella munkásságának egyik igen fontos területe a magyar helyesírás, valamint a helyesírás tanításának módszertani vonatkozásai. Nemcsak cikkei, tanulmányai, több évtizedes oktatói tevékenysége, hanem például a helyesírási versenyek szervezése is ezt bizonyítja. A Nagy J. Béla helyesírási verseny a felsőoktatási intézmények hallgatói számára 1987-ben Egerben indult, és Bozsik Gabriella tanárnő a kezdetektől a lelke volt ennek a rendezvénynek. Magam is a verseny kapcsán ismertem meg őt, és kapcsolódott össze hosszú időre a versenyen végzett tevékenységünk. Nem véletlen az sem, hogy éppen az ő tollából született meg a verseny 20 éves jubileumára való visszatekintés is (Bozsik 2017, 2019). Módszertani vonatkozásban pedig szinte a helyesírás minden részterületével foglalkozott: a külön- és az egybeírással (2011, 2013), a tulajdonnevekkel (2007a, 2007b), azon belül is kiemelten az intézménynevekkel (1993, 1994) és a földrajzi nevekkel (2000, 2004); összegezte a helyesírás-tanítás tanulságait (2003), és készített gyakorlatsorokat is (1996, 1998, 2007c, 2009). Születésnapja tiszteletére ehhez a témakörhöz szeretnék kapcsolódni néhány gondolattal. Azt a kérdést helyezem a középpontba, hogy vajon a középiskolai gyakorlatban hogyan súlyozzuk a helyesírási hibákat a javítások során, és ezek mögött milyen meggondolások, milyen esetleges elméleti megfontolások állnak, továbbá mit lenne érdemes újragondolni.

\section{A magyar helyesírás tartományai}

A 21. század elejére vitathatatlanná vált: a magyar helyesírás, amely a kezdetektől akadémiai státuszban van (a státuszkérdésre lásd pl. Laczkó 2018), rendkívül magas presztízsértékkel rendelkezik. Jóllehet a központi szabályzat valójában ajánlásként fogalmazódik meg, a helyesírás preskriptív normája miatt az írásgyakorlat gyakorlatilag kötelező jellegűként kezeli. Erre mutat az a fajta szankcionálás (ma már pozitív attitűddel), ahogyan az iskola kezeli a helyesírási hibákat; az az általánosítható tapasztalat, hogy az online térben igen gyakori, hogy a résztvevők egymást a helyesírási teljesítmény alapján ítélik meg (lásd a helyesírásnáci kifejezést); ${ }^{1}$ továbbá nagyon fontos, hogy a nem anyaországi magyar írásgyakor-

1 Ismeretes a nyelvtannáci kifejezés is, és az a tapasztalat, hogy ez a „terminus” is többnyire a helyesírásra vonatkozik. Nyilvánvaló, hogy az emberek számára a mindennapi írásgyakorlatukban a helyesírás az, amely a leginkább feltűnő, amely a szabályozás okán megfogható, érzékelhető és megítélhető. 
lat sem hozott létre a központitól eltérő szabályozást, hanem elfogadja az akadémiai állásfoglalást. Az viszont, hogy a helyesírásra nem egyformán van mindenkinek szüksége, már nem ennyire kétségtelen tény, így nagyon hangsúlyossá kell tenni, hogy több helyesírási tartományt kell megkülönböztetni. Hiszen más mélységben kell ismernie és használnia a rendszert a kisiskolásnak, mint a professzionális írásbeliségben a kiadványok előkészítésével foglalkozó szakembernek vagy a szaknyelvi fordítónak. Ezen az alapon alakult ki a négy helyesírási tartomány, amelyet négy egymással összefüggő helyesírási kiadványhoz köthetünk. A központi bázist értelemszerűen az AkH. ${ }^{12}$ jelenti, amely 2015-ben jelent meg 31 évvel az elődje után. Alapvetően nem változott meg a szabályzati korpuszkérdés, sem a rendszert alakító norma, az alapelvek helyzete, a változtatás oka a nyelvben bekövetkező változások (a magyar helyesírás a kezdetektől nyelvkövető jellegű) és az úzus felől felmerülő igények voltak. Az akadémiai bizottság a változtatásokat három elv mentén igyekezett megvalósítani: 1) a korpusz mint az úzus reprezentációja, 2) a rendszer és 3) az első két pont kettő között megteremtendő konszenzus hármassága mentén. Az akadémiai szabályzat mellett az iskola alsóbb évfolyamai számára létezik ennek a leegyszerűsített változata, amely a 11. kiadás kiegészítőjeként Helyesírásunk (Gráf-Fábián-Szemere 1999), mai átdolgozott változatában pedig Kis magyar helyesírás (Siptár-Keszler-Tóth 2016) címmel jelent meg. A központi szabályozás másik oldalán pedig a helyesírási kézikönyvet találjuk, amely túlmutat a helyesírási szabályzaton, és olyan írásgyakorlati tudnivalókat, ajánlásokat is megfogalmaz, rendszerez, amelyek a központi szabályzatnak nem lehetnek részei (Laczkó-Mártonfi 2004). Ez a három tartomány egyfajta rész-egész viszonyban van egymással. Így a különböző iskolafokok és a professzionális írásbeliség, a kiadók stb. igényei is teljes mértékben kielégíthetők. Negyedik tényezőként - mindegyikkel értelemszerüen erős átfedésben - jelennek meg továbbá a szaknyelvi helyesírási szabályozások. A szaknyelvi helyesírások részlegesen jelen vannak az iskolai oktatásban, hiszen a különböző tudományterületek iskolai terminológiáját érintik, és természetesen a szakmai-tudományos írásbeliség részét képezi a professzionális írásbeliségnek, a szöveggondozásnak vagy a szakfordításoknak is.

A magyar helyesírás a szaknyelvek szabályozásában komoly munkát végzett a korábbi időszakban. Az elmúlt néhány évtizedben megszületett a műszaki, katonai, közgazdasági, orvosi, kémiai, állat- és növényrendszertani, földrajzi névi helyesírási szabályozás (vö. Fábián 1993; Mártonfi 2018), és hamarosan megjelenik a fizikai helyesírási szótár is. A szaknyelvi helyesírások tekintetében azt látjuk, hogy kétféle megoldási lehetőség kínálkozik a szabályozásukra. Ha egy szakterület ugyanis olyan terminológiával rendelkezik, amelyik az írásgyakorlatában nem tér el az alapvető, a helyesírás normáinak megfelelően működő szabályoktól, tehát ugyanazok a nyelvi tényezők alakítják, csak esetleg jellegzetes speciális vonásokat mutat, ${ }^{2}$ akkor elegendő, ha a terminológiát szaknyelvi

2 Például az orvosi nyelvben a latinos vagy magyaros írásmód kérdése, amely ott sokkal profiláltabb tényező, mint általában a sztenderd helyesírásban, vö. Bősze-Laczkó 2009; Ludányi 2016; Bősze 2018. 
helyesírási szótárak tartalmazzák összegző bevezetővel, amely kiemeli az adott szaknyelv terminológiájának rögzítésére vonatkozó leglényegesebb tudnivalókat, külön szabályzatra nincsen szükség. Ha azonban egy szaknyelv nómenklatúrával rendelkezik, azaz a terminusok leírásában nem a sztenderd szabályok az irányadók, akkor szükség van külön szabályzat kidolgozására is. Jellegzetesen ilyen a kémia, az állat- és növényrendszertan, valamint a földrajzi nevek írása.

\section{A helyesírás az oktatásban}

Természetesen a helyesírás elsajátítása már magával az írástanulással megkezdődik, hiszen ennek alapja, hogy a szavainkat írásban rögzítsük. A magyar helyesírás legelső alapelve a fonematikus elv, ezen belül legelsőként a kiejtés elvének megfelelő rögzítési mód, amelyet a szóelemzés, valamint a fonematikusságon belül értelmezhető hagyomány követ. Érdemes arra felhívni a figyelmet, hogy az oktatásban alapelvként az írásmódokat emlegetik, jóllehet soha semelyik szabályzatban sem alapelvként, hanem írásmódként reprezentálódtak. Alapelven a magam részéről a helyesírási normákat értem, amelynek négy területe van: 1) a fonematikusság, amelynek része a kiejtés és a szóelemzés mint írásmód; 2) az értelemtükröztetés, 3) a hagyomány, amelyet a fonematikussággal és az értelemtükröztetéssel szemben érvényesített kivételként kell kezelni, valamint 4) a teljes rendszert átszövő egyszerűsítés (vö. LaczkóMártonfi 2004, 2008; Laczkó 2018). A fonematikus alapelv elsajátításának, kiegészülve a fonematikussággal szemben álló hagyománnyal (lásd pl. ly kérdése), tehát az írástanulással párhuzamosan kell megvalósulnia, stabilizálódnia és rutinszerűvé válnia. Ez persze nem jelenti azt, hogy ne kellene folyamatosan, később is a szavak írásképét megtanulni, pusztán arról van szó, hogy az alapokat az írástanulással együtt kell megérteni és elsajátítani. Az értelemtükröztetés alapelve azonban ennél sokkal komplexebb kérdéseket vet fel - ugyancsak a hagyományértelmezéssel együtt -, hiszen ebben az esetben belépnek a rendszerbe szerveződő szabályok, amelyek mechanikusan alkalmazhatók. Jól illusztrálja a fentieket a következő megállapítás: „A helyesírás tanítása és tanulása az iskolai nevelésben egyetlen évfolyamhoz vagy egyetlen iskolafokozathoz sem köthető kizárólagosan. Ezen a területen minden életkornak és minden iskolatípusnak megvannak a saját nevelési céljai és feladatai" (Antalné Szabó 2008). Antalné három alapvető célt fogalmaz meg a helyesírás-tanulásban: 1. a példák (a szavak, a szókapcsolatok) helyes írásképének a megtanulása; 2. a helyesírási szabályok megértése, megtanulása és alkalmazása; 3. a helyesírást segítő eszközök (a helyesírási kézikönyvek és a számítógépes helyesírás-ellenőrző programok) funkcionális alkalmazása (Antalné Szabó 2008). Az 1. pont kötődik a fonematikussághoz, a 2. pont az értelemtükröztetéshez, ahol a rendszerszerüséget nyelvi-nyelvtani szabályok egymásba fonódó összetettsége alakítja ki (részben már ide tartozik a szóelemző írásmód is). A 3. pont hangsúlyozása pedig nagyon fontos: senki nem tudja a teljes helyesírási rend- 
szert és a szótárat fejben tartani (vö. Fábián 1986), vagyis a legfontosabb cél az, hogy tudatosuljon: mely esetekben kell valakinek ezekhez a segédeszközökhöz nyúlnia és használnia őket.

Nyilvánvaló tehát, hogy maga a magyar helyesírási korpusz nem homogén abból a szempontból sem, hogy az egyes részterületek elsajátítása mennyire igényel előzetes nyelvi-nyelvtani tudatosítást, ez mennyire kell, hogy mély legyen, így mikor érdemes sort keríteni rá az iskolában. A különírás-egybeírás például köztudottan a magyar helyesírás legneuralgikusabb pontja, és ennek egyik oka az, hogy a mögöttes szabályrendszer a szószerkezetek és az összetételek közti distinkció felismerésén alapul, amely szemantikai és grammatikai tudást igényel. A tulajdonnevek körében a közvélekedés szerint a földrajzi nevek írása bizonyul meglehetősen nehéznek, ennek viszont az az oka, hogy ebben az esetben egy szaknyelvi nómenklatúra megértésére van szükség. Mindez pedig összefüggésben van a hibázások megítélésével is. Érdemes összegezni azt, hogy a 2020-as nyolc-, hat- és négyosztályos magyar nyelvi felvételik, valamint az érettségi javítási útmutatója mit tartalmaz a helyesírás javításával kapcsolatban. A középpontba a középszintű magyarérettségi javítási útmutatóját állítom. ${ }^{3}$

\section{Instrukciók a helyesírás javítására vonatkozóan}

Az iskolai oktatásban a helyesírás javítása hagyományosan a hibák súlyozásával történik ${ }^{4}$. Négyféle súlyossági fokot különböztethetünk meg (lásd a 2020as érettségi javítókulcsának melléklete, amelyet az alábbiakban elemzésem kiindulópontjaként használok, W1): a súlyos hibának két típusa van, az egyik három, a másik két hibapontnak minősül. ${ }^{5}$ A következő az enyhe hiba kategóriája (1 hibapont), és a negyedik csoportot a központozási hibák jelentik, erre összesen, a hibázások számától függetlenül 4 hibapont adható.

4.1. Mi tartozik a legsúlyosabb hibák közé? A felsorolás szerint a fonematikusság köréből a mássalhangzók időtartamának a tévesztése, a szóelemzés elvét érintő tévesztések, külön kiemelve a felszólító módú igealakokat, az értelemtükröztetés köréből a tulajdonnevek kezdőbetűjének az elhibázása, az igekötő írásmódjára vonatkozó rontások, továbbá a hagyomány köréből a j-ly tévesztése.

Egyértelműnek tűnik, hogy ez a lista a korábbi típushibákon alapszik, ám némileg végigondolatlanul. Úgy vélem, időszerű lenne bizonyos árnyalással élni. A szóelemzés elvének elhibázása, ami a hasonulásokat vagy az összeolvadást illeti, teljes mértékben releváns, már csak azért is, mert a morfológiai elemzés stabilitását ezen a szinten - mint említettem - az írástanulás kezdeti

3 Az emelt szintű érettségi javítási útmutatója ebben a tekintetben szóról szóra megegyezik a középszintűével.

4 Erről mint problémafelvetés lásd Elekfi 2005-2007.

5 A korábbi időszakban a 3 pontos súlyos hibát még durva hibának nevezték. 
fázisától gyakorolni kell, tehát az érettségi idején ennek valóban rutinszerűnek kell lennie. Az már kevéssé érthető, hogy ebből a problémakörből miért kell külön kiemelni a felszólító módú igealakokat, hiszen a jellemzőnek tekinthető játsszák, vonzzuk formák ${ }^{6}$ tévesztése alapvetően a hasonulás fel nem ismerésére vonatkozik, míg például a lőj, szőj elhibázása esetén a mássalhangzó időtartamának helytelen alkalmazása történik a felszólító mód jelében (*lőjj). Mindkét szempont szerepel a felsorolásban, a felszólító mód kiemelése így szempontkeveredést okoz.

A javítókulcs megadja a mássalhangzók kapcsolódásának az eseteit, a hasonulásokon és az összeolvadásokon kívül viszont ide került a nyúlás és a rövidülés. Ez azonban erősen átfedésben van a korábbi ponttal: a mássalhangzók időtartamának a tévesztésével. A rövidülés és a nyúlás esete különbözik akkor, ha ez a szó belsejében vagy a morfémahatáron következik be. Ha a szó belsejében lévő mássalhangzó sztenderd kiejtése korrelál a leírt formával, akkor a rögzítés a kiejtés írásmódja szerint történik. Ha azonban nem korrelálnak, lásd az iskolai „klasszikusokat” (lesz, egy, kisebb), akkor véleményem szerint már a hagyomány alapján írunk, hiszen ez esetben meg kell az adott szó írásképét jegyezni. Nyilvánvalóan, ha a rövidülés vagy a nyúlás a morfémahatáron következik be, akkor a jelenség a szóelemzéshez tartozik, amely egyértelműen grammatikai alapú, világosan tudható, megtanulható. Ebből az következik, hogy az első esetben (lásd pl. az ingadozó kiejtésü alakok: agancs, biliárd, briliáns, csat, hegeszt, illetve elhesseget, frottír, guggol, affektál, konnektor, mállik stb.) akkor stabil valakinek a helyesírása, ha ezekkel a szavakkal többször találkozott, és begyakorolta, de szabály tudása nem kapcsolható hozzájuk. Ellenben a szóelemzés ide vonható esetei nem ebbe a kategóriába tartoznak, ezek mechanikusan, a szabályok alapján alkalmazandó helyesírási kérdések, például: varrsz, vonzzuk, álltok, álld, halld, kedvvel, érvvel, karddal stb. Nem kétséges, hogy a két látszólag hasonló jelenséget nem lehet a hibázások tekintetében azonosan kezelni, mert eltérő forrásból erednek. A legsúlyosabb hibák között csakis a szóelemzéssel összefüggő mássalhangzós tévesztések maradhatnának, a szó belseji csakis finomítással.

A szó belseji mássalhangzók tévesztésének megítélésében ugyanazt az „engedményt” teszi a javítókulcs, mint az ly-nál: a közhasználatú szavakban kell csak súlyos hibának venni az elrontását. A megoldókulcs zárójeles példái azonban erősen elgondolkodtatóak. A középszintű kulcsban ezek szerepelnek: esszencia, kommunikáció, immunis. Ez a példasor több okból is érthetetlen. Miért éppen ezek jelzik a „közhasználatú" szavak esetét? Miért nem például maga a mássalhangzó szó, amelyben a hosszú ss elhibázását valóban súlyosabbnak lehet tekinteni, hiszen a gyerek a tanulmányai során sokszor rögzítette ezt az alakot. Az esszencia azonban 2015-ben változott meg a szótárban (szabály ehhez semmi esetre sem kapcsolható): a kétféle, rövid és hosszú mássalhangzós írásmód közül

6 Kétségtelen, hogy a játsz + j morfémaszerkezet írásában típushibának számít a rövid sz rögzítése. Köszönettel tartozom Csekő Györgyinek a Szinyei Merse Pál Gimnázium vezető magyartanárának, hogy rendelkezésemre bocsátotta a javítás során szerzett és összegezett tapasztalatait. 
az *eszencia formát a bizottság törölte: azaz mindkét jelentésében ugyanúgy kell írni a főnevet. Kétségtelen, hogy 2017 óta az új szabályozás szerint kell végezni az érettségi javítását, de vajon éppen egy szótári változást, egy nem is túl gyakori használatú jövevényelemet kell kiemelni mint legsúlyosabb hiba? Az immunis ugyancsak megkérdőjelezhető: valóban közhasználatú szó? Egyébként ennek a szónak a helyesírása is megváltozott, csak éppen a magánhangzó tekintetében: a hosszú ú-ból lett rövid. Elhibázottnak tartom, hogy éppen ilyen példák jelenjenek meg a javítási útmutatóban, már csak azért is, mert érzékelhetően jövevényelemek, és ezek helyesírása sokkal inkább változhat az idők során, mint a már egyértelműen a magyar szókészletbe tartozó szavak írásképe (lásd az 1984-ben megváltozott helyesírású szavakat: mamut, buldog, aligátor, konkurencia stb.; úgy vélem, hogy összírásgyakorlati szinten ezeknek hosszú idő kellett, hogy valamenynyire stabillá váljanak a gyakorlatban). ${ }^{7}$ Valójában a közhasználatúság fogalma is nehezen értelmezhető, egy bizonyos határon túl már intuitív. Felmérések arra nézve nincsenek, hogy a 18-19 évesek esetében ez hogyan határolható be pontosan. Rugalmasan kell kezelni, nyilván a javító tanár gondolkodásmódjának, attitűdjének is a függvényében. (Azt persze meg kell említeni, hogy középszinten a javító tanár jól ismeri a diákjait és az elvárásrendszert, emelt szinten pedig értelemszerűen magasabbra kell tenni a mércét.) ${ }^{8}$

A fentieken kívül a legsúlyosabb hibák közé tartozik a fonematikussághoz tartozó hagyomány köréből a $j$ és az ly tévesztése. A javítókulcs ezt így határozza meg: „az ly - $j$ tévesztése közhasználatú szavakban és toldalékokban, az ly - j hiánya vagy kiejtés szerinti jelölése". A meghatározás második felét nehezen lehet értelmezni. Hol vegyük hibának a hiányt? Mit jelent az, hogy kiejtés szerinti értelmezés? Kétségtelen tény, hogy a mássalhangzó-jelölésben a legtöbb gondot a $j$ és az ly kettőssége okozza, hiszen a mai kiejtés szerinti azonos fonémának két betűjel felel meg. Ez a fonematikus írás részleges feladását jelenti. A rögzítés azért kérdéses, mert nyelvtani értelemben vett szabályok nincsenek arra, hogy mikor kell ly-t és mikor j-t írni egy-egy szóban. Vagyis tulajdonképpen minden egyes esetben meg kell tanulni a helyes rögzítést. Bizonyos fogódzók léteznek, de ezek közül is csak azt tekinthetjük stabilnak, hogy a magyar toldalékolási rendszerben nincs ly-nal írandó toldalék (a korábban ly-os képzők mára tudniillik elavulttá váltak, teljes mértékben improduktívak, a velük alkotott korábbi képzett szavakban a tő és a képző transzparenciája gyakorlatilag megszúnt). Ebből következően még inkább fontos annak hangsúlyozása, hogy ezt a javítási utasítást csak és kizárólag közhasználatú szavakra alkalmazzuk,

7 Jó példa erre a Mammut budai üzletközpont. A névadás idején már mamut volt a főnév írásképe. Ennek ellenére az intézménynév helyesírásából különösebb felháborodás soha nem lett. De a Battai Bátor Bulldogok rögbicsapat esetén sem, holott a buldog szót nem hosszú /l-lel írjuk. Mindkét név a mai mapig hosszú mássalhangzóval írandó.

8 A javítókulcs meghatározza a közkeletűség megítélésének a kritériumát. „A közkeletű szó fogalma bizonyos fokig környezet- és műveltségfüggő. Megítélésében meghatározóak a középiskolai tanulmányok, ugyanakkor a vizsgatárgy szakszókincse közkeletűnek tekintendő (pl. metafora)." 
amelyek nem azok, hanem népnyelviek, archaikusak, nem a központi szókészlethez tartoznak, ne vegyük bele ebbe a kategóriába. És mivel ebben az esetben teljesen nyilvánvaló, hogy újabb ly-os szavak a magyarban nem keletkeznek, az idegen átvételekben bizonyosan $j$ fog megjelenni a magyaros átíráskor vagy a szó jövevényelemmé válásakor, így ezek a közkeletűnek tartott ly-os szavak listázhatók, a lista véges elemszámú halmazt alkot. Az Osiris-helyesírás készített egy listát, amely tartalmazza azokat a szavakat, amelyek magyar szótárakban előfordulnak, és ly-os írásmódúak. Összesen 244 szó szerepel ebben (LaczkóMártonfi 2004: 64-67), amelyből könnyen összeállítható lenne egy olyan lista, amelyben szerepel az összes közhasználatú előfordulás. Ez alapul szolgálhatna a javításhoz. Az ezen kívül eső helytelen írásmódot pedig nem lenne szabad a legsúlyosabb hibák közé sorolni. ${ }^{9}$

A legsúlyosabb hibák közé az értelemtükröztetés köréből két eset került. Az egyik a különírás-egybeírás körét érinti: ez az igekötő írásának hibáit jelenti. Tapasztalatom szerint itt leginkább az okoz gondot, amikor az igekötő és az ige vagy annak főnévi igenévi származéka közé ékelődik elsősorban a segédige vagy a segédigeszerün használt igealak: meg tudja nézni, be akarja csukni, ki szokta színezni, meg találja ütni stb. Ebben az esetben valóban tekinthetjük az igekötő és a segédige egybeírását súlyos hibának. ${ }^{10}$ Ebben az esetben leginkább arra van szükség, hogy meghatározzuk az igekötők körét, ugyanis ez sem teljesen zárt szófaji kategória, valamint több olyan megvalósulás is lehetséges, amikor egy adott nyelvi elem igekötőként és határozószóként is funkcionál: újra kezdi, újragondol; végig kitart, végigvisz; benn áll (a szobában), bennreked (vhol); legfőképpen pedig: ide tartozik vagy idetartozik stb.

Leginkább azt kellene végiggondolni, hogy a külön- és az egybeírás körén belül melyek azok az esetek, amelyek ugyancsak pontos szabályok szerint mechanizálhatók, megérthetők, így magabiztosan alkalmazhatók. Véleményem szerint ilyen a formális szabályok közül a jelöletlenség, azaz a tárgyas, határozós és birtokos jelzős összetételek kategóriáján belül a jelöletlenné vált összetételek: favágó, koleszterinszegény, falvédő stb. (tehát koleszterinben szegény, de: koleszterinszegény). A mellérendelő összetett szavak írása is határozottan és pontosan elsajátítható, a toldalékolási próba szinte kivétel nélkül működik (kötőjelezés vs. teljes egybeírás: búbánat, de: izeg-mozog). Az ezekben történő hibázások tehát súlyosabban ítélhetők meg. Nyilván nem sorolhatók ide a kizárólag szemantikai alapú egybeírások vagy a hagyományos, azaz kivételes írásmódú formák, továbbá a formalizálható hagyományon alapuló rendszerszintű megoldások sem (pl. az 1+1, 1+2, 2+1 szabály, amely azért nem mechanizálható minden esetben, mert nem olyan egyértelmű a gyakorlatban, hogy például mi számít anyagnévnek),

9 Nyilvánvalóan a lista összeállításhoz felmérést is kellene végezni az adott korosztály körében, számításba véve kiindulópontként a tankönyvi szövegekben előforduló szókészletet a terminológiával együtt.

10 Különösen ügyelni kell az igekötő írására, ha az igekötőhöz tartozó ige vagy igei származékszó elmarad, és csak az igekötő és az eredetileg közbeékelődő igei elem van feltüntetve, például kérdésre adott válaszban: Meg van töltve? Meg van. 
a szótagszámlálási szabály vagy a mozgószabályok sem, ez utóbbiak már csak azért sem, mert nincs teljes kötelezőségi vonatkozásuk a rendszeren belül.

A másik ebbe a csoportba tartozó eset a tulajdonnevek köréből való. A legsúlyosabb hibák közé tartozik a megoldókulcs szerint tehát: „kis- és nagy kezdőbetű tévesztése közhasználatú tulajdonnevek (pl. Magyar Tudományos Akadémia, Természet Világa), melléknevek és egyelemű tulajdonnévből képzett melléknevek (pl. francia, balatoni, vendéglátóipari, adys) esetében". Ismét az látható, hogy ennek a kérdéskörnek az árnyalt és alapos átgondolása nem igazán történt meg. A helyesírásban a tulajdonnevek rendszere egyértelműen a legösszetettebb kategóriát jelenti. Egyrészt nem nyelvtani, hanem pragmatikai megalapozottságú nyelvi típus: tulajdonnév az, amit a nyelvhasználatban akként alkalmazunk. Egyedei közé egy- és többelemű formák is tartoznak, és típustól függően vannak köztük olyanok, amelyek törvényi szabályozás alá esnek (pl. a személynevek köre, a hivatalos intézménynevek és a márkanevek), erős kodifikációval rendelkeznek (pl. a földrajzi nevek, amelyek a szakmai helyesírások körébe tartoznak alapvetően, de ide sorolhatók a címek is), és olyanok, amelyekben maga a néviség kérdése is rugalmasabban kezelendő (állatnevek, tárgynevek, részben, legalábbis a népi elnevezésekben, a csillagászati tulajdonnevek ${ }^{11}$ vagy a díjak, kitüntetések elnevezései). Ha még azt is hozzátesszük, hogy a tulajdonnevek heterogén írásmódú kategóriájában nemcsak a nagy kezdőbetű használata lényeges, hanem a névterjedelem jelölése is, ${ }^{12}$ és mindezt megpróbáljuk azzal is egybevetni, hogy mit jelent ebben a csoportban a közhasználatúság, világossá válik, hogy nagyon átgondolt árnyalásra lenne szükség a hibák súlyozásában. Gondoljunk csak arra, hogy a sokat emlegetett Gellérthegy, Margitsziget és Lánchíd problémaköréhez egy budapesti kisgyereknek teljesen kézenfekvő, nyilvánvaló és megtapasztalt földrajzi nevek tartoznak, ugyanezek egy vidéki általános iskolás számára már korántsem biztos, hogy azok..$^{13}$ De még az sem adhat ebben támpontot, hogy vajon a földrajzkönyvek tulajdonnévanyaga kiindulópont lehet-e ebben a vonatkozásban. Közhasználatúnak számítanak-e a gimnáziumi földrajzanyag következő példái:

11 A csillagászati elnevezések a szakmai helyesírások közé tartoznak, ám mai napig nem rendeződött megnyugtatóan a helyesírási kodifikációjuk, nem született meg a szaknyelvi szabályzat és szótár. Lásd erről legutóbb W2.

12 Lásd részletesen Laczkó-Mártonfi 2004: 151-153; Laczkó 2016: 183-184.

13 Arról nem is beszélve, hogy a kivételként tanított egybeírása ezeknek a megnevezéseknek teljes tévedés, tökéletesen félrevezető. A Gellérthegy és a Margitsziget kettős írásmódú: egybe akkor kell írni őket, ha városrészként rögzítjük őket, de természetföldrajzi névként kötőjelesek. Az sem igaz, hogy az egybeírás erősebb formálisan, mint a kötőjelezés, azaz akkor, ha nem lehet a fenti distinkciót megtenni, akkor az egybeírást kell választani. Soha nem ezt tesszük a Hármashatárhegy vagy a Jánoshegy esetében, jóllehet ezek is városrésznevek, tehát relevánsan egybe is lehet írni őket. A Lánchíd esetében pedig azt kell tudni, hogy a teljes megnevezés: Széchenyi lánchíd, ahol a névbe belekerült a híd típusának a megjelölése, amely jelentéssürítő összetételként csakis egybeírva helyes. A Lánchíd a név röviden használt alakja, és csak ekkor nagybetűs, az egybeíráson pedig nem változtat a névnek ez a fajta lerövidülése. Tehát ez sem tartozik a kivételek közé. 
Indokínai-félsziget, Dél-kínai-tenger, Nagy-Szunda-szigetek, Nagy-Hingán, Zöld-fokiszigetek, Déli-Shetland-szigetek, Keleti-Sierra Madre, Ouagadougou, Nagy-New York stb.? Úgy vélem, semmi esetre sem. Még kevésbé lehet meghúzni bármiféle korrekt határvonalat abban, hogy egy érettségiző gyereknek milyen intézményneveket, márkaneveket, díjneveket stb. kell magabiztosan ismernie, különösen ezek erősen változó volta miatt.

Továbbá feltétlenül el kell különíteni a nagy kezdőbetű tévesztését a fordítottjától. A nagybetű használata a kicsi helyett kevéssé súlyos hiba, több okból. Létezik egyrészről az úgynevezett lokális tulajdonnevesülés kérdése vagy az érzelmi alapú nagybetűsítés - egymástól nem teljesen függetlenül. Erre a jelenségre a korábbi szakirodalom sem hívta fel kellően a figyelmet, ám az új szabályzatba részben már belekerült ez a kérdéskör, és a kis- és nagybetűhasználattal kapcsolatosan több új, úgynevezett fakultatív szabály is létrejött. Ennek ismeretében lenne célszerủ a javítási útmutatót ezen a ponton továbbgondolni.

Először is a lokális tulajdonnevesülés azt jelenti, hogy adott szövegtípusokban, jellegzetes tematikus kontextusban bizonyos közszavak, amelyeknek nem létezik lexikalizálódott tulajdonnévi formájuk, tulajdonnévként funkcionálnak, például a jogi szakszövegekben az Alperes, Felperes, Kormány, Eladó, Vevő; asztrológiai írásokban a Túz, Víz, Föld, Levegő stb. (Az AkH.12 a 148. szabálypontban szól erről a jelenségről új pontként.) Másrészt megengedőbb lett az új szabályozás az intézménynevek írásában [l. AkH. ${ }^{12}$ 188. d)]. Az adott konkrét tulajdonnévi referencialitású intézménytípust jelölő elemek (minisztérium, iskola, egyetem, bizottság, intézet) eddigi kötelező kisbetűs írása önálló használatban fakultatívvá vált. A szabályzat megszövegezése szerint, bár ajánlatos a kis kezdőbetű használata (a bizottság döntése értelmében, az iskolában felálló új vezetés stb.), a lokális tulajdonnevesülés jelenségét elismerve bizonyos szövegtípusokban vagy tematikus kontextusokban ezen a ponton is elfogadható a nagy kezdőbetű (a Kutatóintézet kidolgozta; a Minisztérium rendeletei stb.). Ugyancsak nem írja elő a szabályzat az eddig kötelező kisbetűs írást az intézmények kisebb egységeinek a megnevezésében (189. c pont: Bölcsészettudományi Kar gondnoksága/Gondnoksága), a nem állandó bizottságok megnevezésének a leírásában (189. c pont: koordináló bizottság / Koordináló Bizottság), valamint a rendezvények, rendezvénysorozatok, társadalmi-politikai mozgalmak, programok stb. nevének az írásában (191. pont: nemzetközi orvoskongresszus / Nemzetközi Orvoskongresszus). Ezekben az esetekben nem a fent említett lokális tulajdonnevesülésről van szó, hanem a közszó vagy szerkezet és a tulajdonnév nem élesen elkülöníthető, hanem erőteljes kontinuitást mutató határsávjáról. Az a fajta megítélési probléma, hogy a kérdéses alak önálló intézménynév-e, vagy sem, nem szűnik ugyan meg, de döntés kérdése lehet az, hogy az írásbeli megnyilatkozásban melyiket választjuk. Jóllehet a szabályzat óvatos megfogalmazása továbbra is a kisbetűsítést preferálja, nem zárja ki a nagy kezdőbetűt sem.

A fentiekkel ellentétben sajátosan nem esik szó fókuszáltan az új szabályzatban az úgynevezett érzelmi alapú nagy kezdőbetűkről. Ez elsősorban az események megnevezéseit érinti. Részben átfedésben lehet a jelenség a lokális 
tulajdonnevesüléssel, részben a köznév és a tulajdonnév határsávjával. Az eseményneveket a szabályozás egyértelműen kisbetűvel kodifikálja, ám például egyházi szövegekben, de akár magánjellegű írásokban (ilyen jellegű szövegalkotási feladat lehet a magyarérettségin) nem tekinthető hibának a nagybetűs használat sem (karácsony, pünkösd, anyák napja). Azért ismertettem bővebben a változásokat ezen a ponton, hogy világossá váljon: az új szabályzat a fentiekben sokkal megengedőbbé vált, így a javítási metódusban is árnyaltabban, specifikáltabban kell kezelni az utasításokat. Ugyanez vonatkozik a tulajdonnevek melléknévi származékaira is, illetőleg a melléknevek alapvető nagybetűs írására. A melléknevek nagy kezdőbetűsítése ugyanis erősen lóg a levegőben az útmutatóban, az egyetlen népnyelvi példa (francia) arra enged következtetni, hogy a javítókulcs megfogalmazójának az angol nyelvi hatás vált emergenssé ebben a vonatkozásban (Hungarian, English); ezt azonban semmiképpen nem a legsúlyosabb hibák között tartanám számon. Különösen annak fényében, hogy a főnevek kezdőbetűjének tévesztése enyhe hibának számít. Az egyelemű tulajdonnevekből képzett melléknevek rontása viszont jól körvonalazható, ennek elhibázása a kezdőbetű tekintetében valóban elgondolkodtató, hogy a legsúlyosabb vagy a súlyos hibák közé tartozzon-e. Vajon egy szinten kezelendő a szóelemzés elvének tévesztésével a megítélésben? És hogyan viszonyuljon ehhez a többelemű egybeírt tulajdonnevek melléknévképzős alakjaiban történő hibázás? Az adys és a balatoni rontása a legsúlyosabb hibák közé tartozik, a budapesti vagy balatonfüredi helynevekből képzett mellékneveké viszont nem? (Avagy ez utóbbi két példa is egyelemú lenne a megoldókulcs szerint?) Egyáltalán nem világos továbbá, hogy mit keres a vendéglátóipari melléknév ebben a sorban, amikor biztosan nem egyelemű tulajdonnévből képzett melléknév, még akkor sem, ha a javítókulcs egyeleműség alatt az egybeírtakat is érti.

4.2. Mindezek fényében nézzük meg, hogy mit kell a 2 hibapontos súlyos hibák közé sorolni. Itt négy csoportot különít el a javítókulcs. A fonematikusságon belül a magánhangzók időtartama tartozik ide. Ezzel annak fényében egyet lehet érteni, hogy a magánhangzó-jelölés a mássalhangzókkal ellentétben kizárólag a kiejtés írásmódjához tartozik, nem érinti őket a szóelemzés. Ráadásul a rövidség-hosszúság tekintetében köztudott, hogy az i-í, az u-ú és az ü-ü okozza a legtöbb problémát, amelynek az az oka, hogy a sztenderben a kiejtés ezeknél a magánhangzóknál a legkevésbé megállapodott. Nyilvánvaló, hogy a kiejtés és a helyesírás normája nagyon eltérően kezelendő (vö. Tolcsvai Nagy 1998). A hangzás normája viszonylag nyitottabb, a helyesírásé zárt, a kiejtés időben természetes módon változhat, a helyesírási szabályozás azonban mesterséges, és nem szükségszerűen követi ezt a változást. Jó példa erre az árbóc főnév esete, amelyet a kiejtés ellenére 2015-ig rövid o-val kellett rögzíteni. Ugyancsak a kiejtési és a helyesírási norma eltéréséből adódik, hogy a sztenderd kiejtésbe beletartozhatnak különféle ejtésváltozatok, a helyesírás azonban egyetlen alakváltozatot kodifikál. Ha valakinek a kiejtése a helyesírási változattól eltér, meg kell tanulnia a megfelelő alak írásképét. Ebből tehát az következik, hogy a magán- 
hangzók rögzítésének tévesztését akkor lehet csak súlyos hibaként kezelni, ha az érettségire követelménnyé válik a segédeszközök, elsősorban a helyesírási szótárak funkcionális használata, egyébként tekintettel kell lenni az egyén anyanyelvjárásként hozott ejtésváltozataira, különösen a nem közhasználatú szavak esetében. ${ }^{14}$ Érdemes azt a jelenséget is megemlíteni, amelynek a megítélése a hibázás szempontjából erősen problematikus lehet. Ez az idegen, főként görög-latin eredetű képzők előtt bekövetkező tő belseji magánhangzó-rövidülést illeti, például: kultúra, de kulturális. Itt szabály helyett erős tendencia fogalmazható meg: a rövidülés javarészt bekövetkezik, ám nagyon sok a kivétel: lírikus, gótikus, szólista, utópisztikus (az a-á, e-é vonatkozásában is, de ezek az esetek kevéssé okoznak helyesírási anomáliát). A kivételek nagy száma mindig abba az irányba hat, hogy elbizonytalanítja az írásgyakorlatot, gyakran tapasztalható rögzítési hiba a mitikus, amatörizmus vagy az euforikus esetében. Kérdés pedig ismét az, hogy ezen alakok között egy érettségiző ember számára mi tekinthető közhasználatúnak, és mi nem.

A másik három felsorolt típus az érelemtükröztető írásmódot érinti. Egy a külön- és az egybeíráshoz, egy a nagy kezdőbetű kérdéséhez tartozik, és egy „új” elem a javítókulcs szempontjából az elválasztásra vonatkozik. Meglepően korlátozott az ide sorolt esetek száma és az altípusok is. A tulajdonnevekkel kapcsolatban például semmi nem szerepel ebben a részben, csak az enyhe hibák között tér vissza ez a problémakör. Ami a súlyozást illeti, ezt bizony alaposan végig kell gondolni a fent elmondottak fényében is. Úgy vélem, nemcsak nagyon súlyos és enyhe hiba állapítható meg a tulajdonnevek körében, hanem ennél sokkal összetettebb a jelenség, erőteljesebb közöttük a kontinuitás a hibák szempontjából. A kis- és a nagybetűk kérdésköréből a mondatkezdő nagybetű tévesztése szerepel a két hibapontos tévesztések között. Ez teljesességgel érthetetlen, miért nem súlyosabb hiba. A mondatkezdő nagybetű és a mondatzáró írásjel már az írástanulás nagyon korai fázisában megjelenik, rutinizálódik, pontos szabályok mentén alkalmazandó. Ráadásul az érettségizők nem írnak diktálás után, saját szövegeket hoznak létre, amelyben éppen ezek az alapvető elemek adják a legfontosabb tagolóeszközöket (lásd a központozás kérdését is ebben a vonatkozásban).

A külön- és az egybeírás köréből egyetlen jelenséget emel ki a javítókulcs: ez a tagadószó egybeírása az igével. Nincs egyetlen olyan lehetőség a magyar helyesírásban, amikor a tagadószót az igével, de nemcsak az igével, hanem bármilyen más szófajú szóval egybe kellene írni, sokkal inkább az a néhány szakterminus szokott gondot jelenti, amikor ezt mégis így kell alkalmazni (nemlineáris, nemmágneses, nemnewtoni, nemnedvesítő). ${ }^{15}$ Ebből következően a tagadószó

14 Megjegyzendő, hogy a javítókulcs kitér az a-á, e-é tévesztésére, amelyet enyhe hibának tart. Valójában ezek rontása sokkal inkább figyelmetlenség vagy „diszes” probléma lehet, hiszen ezek nem hosszú-rövid párok, hanem minőségi különbséget hordoznak, így egyetérthetünk a kevéssé súlyos megítéléssel.

15 Ezt a kérdéskört a szabályzat nem, csak a szaknyelvi helyesírások árnyalják (lásd pl. Mártonfi-Sólyom 2020). 
igével történő egybeírása a legsúlyosabb hibák közé kellene, hogy számítson. Látható tehát, hogy ebbe a közbeeső fokozatú kategóriába nemcsak a tulajdonnevek köréből nem került be semmi, de valójában a magyar helyesírás legneuralgikusabb pontjából, a külön- és az egybeírásból sem. Ez utóbbi is csak az enyhe hibák között szerepel újra, miközben a kontinuitás elve ugyancsak érvényes lenne rá.

Az elválasztás a két hibapontot érő rontásoknál bukkan fel, ismét csak specifikálatlanul. Az egyetlen megszorítás a közhasználatúság. Ennek problémájáról már volt fenn szó. Ezt a kérdéskört is érdemes lenne kissé árnyaltabban megközelíteni. Az idegen közszavak és tulajdonnevek elválasztási kérdései ugyanis véleményem szerint nem esnek ugyanabba a súlyossági fokozatba, mint a magyar szókészletbe tartozó elemek szótagolás szerinti elválasztása vagy akár az összetételi határon történő megszakítás szabálya. Márpedig az érettségin a különböző feladatokban az idegen tulajdonnevek minden további nélkül előfordulhatnak, és minden bizonnyal felbukkanhatnak olyan idegen eredetü összetett formák is, amelyek az elválasztás szempontjából problematikusak lehetnek, például: demokrácia, diszkrét, eksztázis, fotografál, instrukció, katasztrófa, konfliktus, konklúzió, mikroszkóp, paragrafus, reklamál, szindróma stb. De megemlíthetők a -gram, -gráf, -gráfia utótagú összetételek külön is, amelyeket általában a szótagolás szabályai szerint kell elválasztani: diag-ram, monog-ram, fonog-ráf, geog-ráfia stb., ám vannak közöttük olyan egyedek is, amelyeknek kétféle elválasztási lehetőségük van: fotog-ráfia vagy foto-gráfia, kartog-ráfus vagy karto-gráfus. Azt kizárólag a szótárak tartalmazzák, hogy mikor élhetünk a kétféle lehetőséggel, és mikor nem. Itt megint csak hangsúlyozni kell a funkcionális szótárhasználati ismeretek fontosságát.

4.3. Az egy hibapontos, másképpen enyhe hiba kategóriája állítható valójában ténylegesen kontrasztív viszonyba az eddigiekkel, vagyis valójában a súlyos és az enyhe hiba a két nagy csomópont. A javítókulcs jelenlegi formájában a súlyos és az enyhe hiba két kulcsrész tehát, a súlyoson belül a két hibapontos rész ebben a formájában átgondolatlan és nem szerencsés árnyalás. Az enyhe hibák között vannak felsorolva azok a jelenségek, amelyek - a fonematikusság kivételével - megjelennek az első, a legsúlyosabb hibákat taglaló csoportban is, azaz itt érzékelhető valamelyest a tényleges súlyozás. Valamint ide kerültek $a z$ "egyéb" esetek.

A ténylegesen "megfogható" kategóriába a külön- és az egybeírás, a kezdőbetű és a tulajdonnevek köréből kerültek ide jelenségek. Valójában a külön- és az egybeírás minden esete specifikálatlanul ide tartozik az igekötő és a tagadószó jelenségét leszámítva. Elég nyilvánvaló, hogy ez ebben a formában nem szerencsés és nem is tartható. Nagyon erős különbséget kellene tenni - ahogy már említettem - a jelöletlenséggel együtt járó összetétellé válás és a pusztán szemantikai alapú között, azon belül is árnyalhatóan. Két olyan jelenséget érdemes erre példának említeni, amely ezt alátámasztja. A minőség- és a mennyiségjelzős kapcsolatok kérdése az egyik. A jelző és a jelzett szó közötti 
szemantikai viszony erősen a kontinuumelv mentén határozható meg, amenynyiben erre nézve nem létezik formális szabály (a jelző szintaktikai szerepét a szórend és nem rag jelöli). Ha például megnézzük a nagy vagy a kis melléknevek szerkezeteit (alkalmi szószerkezetek, kollokációk, összetett szavak: nagyszabású, nagyszámú, nagy számban, nagy összegü stb.), ez teljesen nyilvánvalóvá válik. Jó néhány esetben pusztán az íráshagyomány és nem a szemantikai minőségi változás indukálja az egybeírást. Ezeket senki nem tudja fejben tartani, vagyis itt megint nagyon lényeges elemmé válik az ellenőrzés, a funkcionális szótárhasználat megtanítása. A másik kérdéskör az igei alaptagú állandósult szókapcsolatokból képzett főnevek kérdése: ugyancsak sok esetben az íráshagyomány miatt történik egybeírás: figyelembe vesz, de: figyelembevétel, fejbe lö, de: fejbelövés, nyakon csíp, de: nyakoncsípés stb. Mindenesetre a külön- és az egybeírás kérdéskörét tekintve belátható, hogy a hibázások nem tekinthetők egyforma súlyúnak, egészen eltérően kell kezelni a favágó, a drágakő ('kőfajta') vagy a nagyszámú, illetve a harcbavetés szavak elrontását. ${ }^{16}$

A kezdőbetűk tekintetében ebben a kategóriában jelenik meg a főnevek nagy kezdőbetűsítése mint hiba, elválasztva a melléknevektől. Nem tartom megfelelőnek ezt az eljárást (lásd fenn), ahogy az is kérdőjeleket von maga után, hogy a tulajdonnevek köréből a két, különírt elemből álló tulajdonnévből képzett melléknevek külön meghatározódnak. A példák a következők: New York-i, Csokonai Vitéz Mihály-os, budapest-bécsi. ${ }^{17}$ Mit jelent ez? Megjelenik a kulcsban az egyelemüség (nem is pontosan értelmezhető módon) és a különírt elemek kérdése a melléknévképző vonatkozásában. Nem történt meg annak az átgondolása, hogy a tulajdonnevek esetében a nevek nyelvi felépítése ennél sokkal komplexebb. A névterjedelem jelölése a többeleműség vonatkozásban a földrajzi nevekkel példázható a legeklatánsabban. Vannak a teljes egybeírással rendelkező nevek, amelyekben teljes mértékben érvényesül a képző kisbetűsítő hatása (magyarországi, kisalföldi, gazdagréti), a kötőjeles kapcsolásúak, ahol az -i képző kisbetűsítő hatása már nem teljes körü (sólyom-szigeti, holt-tiszai, de: (sepel-szigeti, Balaton-felvidéki), valamint a különírt elemekből állók, amelyben két lehetőség van: vagy minden elem nagy kezdőbetűs, a melléknévképző ekkor is kétféle lehetőséget rejt (ománi szultánságbeli, de: Suriname köztársasági), vagy a földrajzi köznév kisbetűs, ekkor a melléknévképzőnek nincs betükicsinyítő hatása (Baranya megyei, Kossuth utcai). Ezt az alaprendszert egészíti ki a két- vagy többelemü idegen írásmódú nevek melléknévképzős alakjának írására vonatkozó szabály, amelyre a javítókulcs is hoz példát. A többi tulajdonnév

16 A javítókulcs felsorolt példái nagyobb részben a fenti problémát példázzák, éppen az említett jelenségkörből jelennek meg esetek: nyitvatartás, nagyméretü; továbbá: kémiaszakkör, csoda szép, véghez visz, szabadvers (ez utóbbi példázza a minőségjelzős szerkezetek és összetételek erős határsávját). A vendéglátóipari példa korábban is szerepelt, nem teljesen érthető a megjelenése, lévén a szótagszámlálási szabály még említés szintjén sem reprezentálódik a javítókulcsban.

17 Ha már helyesírási javítókulcs: célszerủ lett volna odafigyelni arra, hogy a nagykötőjel előtt és után ebben az esetben nem tehető spácium. 
írásformája és melléknévképzős alakjaik is nagyjából ezt az alapsémát követik azzal a megszorítással, hogy nem minden eshetőség jelenik meg mindegyikben. Látható tehát, hogy a javítókulcs nem is törekszik még nyomaiban sem ennek a rendszernek a visszaadására és a súlyozás elvégzésére.

Az enyhe hiba kategóriájában három "egyéb" eset van, amely nem szolgál másra, mint hogy lefedje a kimaradó részeket. Egyrészt a nem közhasználatú szavak súlyos hibáit sorolják ide, másrészt azokat a hibákat, amelyek a súlyos hibák között nem jelennek meg. Azt láttuk, hogy a különírás-egybeírás és a tulajdonnevek körében sem teljes a kép (az előbbiből az 1+1, 1+2, 2+1 formális szabályairól, a szótagszámlálási vagy a mozgószabályokról egyáltalán nem esik szó), de teljességgel kimaradtak az idegen szavak, a mozaikszavak, a rövidítések vagy a számok. Jóllehet az idegen szavak írásának esetében nagyon jelentős szerepe van az amúgy sokat emlegetett közhasználatúságnak, a dátum írása lényeges kérdéskör (a központozásban jelenik meg), és a rövidítésekre is vonatkoznak olyan szabályok, amelyek helyesírási relevanciája fontos, és nem csak a központozást tekintve. Harmadikként az enyhe hibák közé kerültek az elírások, a betűcserék, a betű- vagy szótagkihagyások.

4.4. Talán a legtöbb kérdőjelet a központozás kezelése veti fel. A javítókulcs teljesen egyértelmúen úgy reprezentálja ezt a kérdéskört, mintha marginális lenne a helyesírásban. Ezt tarthatatlannak vélem. A mondatzáró írásjelek például mondatfajtákat különítenek el, tagoló és szupraszegmentális szerepük van, grammatikai relevanciával is rendelkeznek, az írástanulás kezdeti fázisától jelen vannak, mégis egy kategóriát alkotnak eszerint például a fakultatív veszszőhasználattal. Az instrukció szerint öt hiba elkövetése jár egyetlen hibaponttal. Ez bizony azt sugallja, hogy nem érdekesek, nem számítanak az írásjelek, holott nem egy esetben az elhibázásuk a szöveg értelmének a megváltozásához vezethet. Nagyon lényeges szerepük van a szövegkonstruálásban, hiszen a szöveg koherenciájához járulnak hozzá az írásbeli szövegek esetében. Ennek be nem látása és láttatása véleményem szerint súlyos módszertani hiba.

Kétségtelen tény, hogy az interpunkció rendkívül komplex és árnyalt. Vannak ugyanis kötelezőségi, alternatív és fakultatív szabályai. Az érettségire minimum a kötelezőségi szabályok ismerete megkövetelendő lenne, és nem az elnéző, hanem inkább a súlyos hibák közé kellene sorolni a rontásukat. Az egyszerü mondat mondatzáró írásjelei teljes mértékben ide tartoznak, de 1 hibapontosnak lehetne tekinteni a tipikus, összetett mondatokat záró írásjelhasználatot is, hiszen a szabály mind az alá-, mind a mellérendelés esetében stabil és világos. Ugyancsak súlyosabb megítélés alá kellene, hogy essen a tagmondatokat elválasztó írásjelek hiánya: az és, s, meg, vagy kötőszók kivételével teljesen egyértelműen alkalmazandó. A felsorolt kötőszavak esetében viszont valóban nagyon nagy a bizonytalanság a gyakorlatban, ezek kezelése a jelenlegi utasítás szerint történhetne, különösen akkor, ha az egyszerü és az összetett mondat határán lévő mondatokban szerepelnek ( $p l$. A tanár feladta ${ }^{\prime}$ ) és a diákok megírták a leckét). Mivel ez a kérdéskör egybecseng a mondatrészek közötti írásjelek 
használatával, így hasonlóképpen kellene eljárni ott is. Értelemszerűen azt nem lehet hibának venni, ha valaki nem pontosvesszőt használ például erősebb széttagolás esetében a tagmondathatáron, hanem vesszőt, de az írásjel megjelenése kötelező jellegü.

A javítókulcs utolsó ide tartozó pontja egy ömlesztett felsorolást mutat, amelynek a végén a „minden, ami kimaradt” jelensége is látható. Ez nagyon nem segít az egységes javításban. Itt jelenik meg az idézés, holott ez megint csak alapjaiban jól elsajátítható kör, és nagyon fontos is, például az egyenes idézés jelensége, már csak a plágium ellen nevelés érdekében is. A dátumok írása mindennapi lehetőség, a szövegtípusok konstruálásakor levelet, önéletrajzot stb. kell írniuk a gyerekeknek, a majdani felnőttéletük során is, érthetetlen a voltaképpeni mellőzése a javítókulcsban. Talán nem merész annak a deklarálása, hogy a jövőben rendkívül fontos lenne a központozás hibáinak a megfelelő súlyozása, a fenti kategóriákba való integrálása és ennek a negyedik csoportnak a meghagyása az olyan jellegű hibákra, és nem csak központozásiakra, amelyek valóban marginálisak a szövegek létrehozásában. Ugyanis egy szöveg megalkotásakor nem azért követjük a helyesírás szabályait, hogy minél egyszerübben létrehozhassuk az írott nyelvi produktumot, hanem a befogadás lehető legegyszerűbb módozata érdekében: azért, hogy az olvasó a lehető legkönynyebben és leggyorsabban jusson el a szöveg általunk szándékolt értelméhez. Ehhez pedig elengedhetetlen a formai tökéletesség, és ebben kifejezetten nagy szerepet kap a központozás is.

\section{A helyesírás javítása a középiskolai felvételikben}

Központi felvételi írásbeli a közoktatásban a nyolc-, hat- és négyosztályos gimnáziumok számára kötelező. A nyolcosztályosba jelentkezők még alsó tagozatba járnak, a hatosztályosba jelentkezők hatodik osztályba. A továbblépés ezekben az esetekben nem kötelező, az általános iskolában maradás is opció lehet. A négyosztályos jelentkezés esetében azonban van egy kötelezőségi váltás: az általános iskola nyolcadik osztálya után a továbbtanulás valamilyen középfokú intézménybe a tankötelezettség szerint jelenleg 16 éves korig kötelező. A felvételi eljárás során a gyerekeknek matematikából és magyar nyelvből kell írásbeli vizsgát tenniük, amely országos szintű. A teszteket és a javítókulcsokat, az érettségi feladataihoz hasonlóan feltüntetik az Oktatási Hivatal honlapján (W3, W4, W5).

A felvételik során a helyesírás javítására vonatkozóan nem találunk olyan részletes és súlyozott útmutatót, mint az érettségi javítási kulcsában. A legkisebbeknél csak arra van instrukció, hogy mennyi hiba esetében hány pont jár, azzal a kitétellel, hogy a központozási hibákért levonás nem történik. Ez azt indukálja, hogy minden hiba egy hibapontot ér. A hatosztályos felvételi megoldókulcsában ennél már árnyaltabb a kép. Érdemes idézni az útmutatót: 
2 pont adható, ha a szövegben az alábbiak közül legfeljebb egy hiba valósul meg:

- egy hiba a közhasználatú szavak egybeírásának terén vagy

- egy hiba a magánhangzó hosszúságának tévesztésénél vagy

- egy elválasztási hiba vagy

- egy mondatkezdő nagybetű tévesztése vagy

- egy-két ékezet hiánya vagy

- legfeljebb két betűtévesztés vagy betűcsere ÉS az előbbiekben ismertetett hibatípusok mellett legfeljebb 1 központozási hiba (javítjuk, de nem vesszük figyelembe az összetett mondatok központozási hibáit); - ha a hibátlan szövegben legfeljebb 2 központozási hiba van (javítjuk, de nem vesszük figyelembe az összetett mondatok központozási hibáit).

1 pont adható, ha a fenti hibatípusok közül legfeljebb kettő van jelen a szövegben, legfeljebb 2 központozási hiba mellett (javítjuk, de nem vesszük figyelembe az összetett mondatok központozási hibáit); ha az egyéb szempontból hibátlan szövegben 3-5 központozási hiba van (javítjuk, de nem vesszük figyelembe az összetett mondatok központozási hibáit).

0 pont adható, ha a szövegben az alábbiak közül valamelyik hibatípus megvalósul:

- igekötős igék írásmódja,

- névutós főnevek egybeírása,

- j-ly tévesztése,

- tagadószók egybeírása egy másik szóval,

- mássalhangzó-hosszúság tévesztése,

- tulajdonnév kezdőbetűjének,

- írásban nem jelölt hasonulás és összeolvadás jelölésének tévesztése;

- ha a 2 pont kritériumainál leírt hibatípusok esetében három vagy annál több hiba található a szövegalkotásban;

- ha 6 vagy több központozási hiba van (javítjuk, de nem vesszük figyelembe az összetett mondatok központozási hibáit).

Látható, hogy valamelyest törekszik az útmutató a hibák egyfajta súlyozására, amely megfelel annak, hogy ettől a korosztálytól már az értelemtükröztetés alapjainak az ismerete is elvárható, ám ezt erősen felszínesen teszi. Fordított a sorrend az érettségi helyesírási javításának az útmutatójához képest. Először szerepelnek az enyhe és a végén a súlyosabb hibák. A hibatípusok felsorolása teljességgel specifikálatlan. A mássalhangzó-hosszúság tévesztése a kiejtés alapján is a legsúlyosabb hibák közé tartozik a szóelemzés és a j-ly rontásával együtt minden árnyalás nélkül. A külön- és egybeírás köréből kizárólag a tagadószó, az igekötő jelenik meg, kiegészülve az érettségihez képest a névutós szerkezetek egybeírásával. Továbbá ugyancsak minden árnyalás nélkül a tulajdonnév kezdőbetüjének a tévesztése jelenik meg. Az enyhébb hibák között a magánhangzó-problémák, a mondatkezdő nagybetű, az elválasztás és 
a közhasználatú szavak egybeírása jelenik csak meg. A központozás kérdésében ugyancsak egy nagyon megengedő attitűdöt tapasztalunk.

Miért aggályos mindez? A felvételiket nem a saját tanár javítja, aki ismeri a gyereket, ráadásul országos szintűek, ami sokkal inkább azt indukálná, hogy nagyon egységesen kellene javítani, megfelelő, árnyalt és pontos útmutató alapján. E fenti összegzés azonban még megközelítőleg sem nevezhető ilyennek. Rosszabb a helyzet a négyosztályos javítókulcsban:

2 pont: legfeljebb 2 ékezet tévesztése az $a$-á és az e-é esetében és legfeljebb 2 központozási hiba (javítjuk, de nem vesszük figyelembe az összetett mondatok központozási hibáit), és eléri a megadott terjedelmet (10 mondat).

1 pont: eléri a megadott terjedelmet (10 mondat), és legfeljebb 2 hibatípus előfordulása az alábbi hibatípusok közül:

- kettőnél több ékezet tévesztése (az a-á vagy az e-é esetében);

- 3-5 központozási hiba (javítjuk, de nem vesszük figyelembe az összetett mondatok központozási hibáit);

- egy hiba a magánhangzók időtartamának tévesztése terén;

- egy hiba az egybeírás-különírás terén, kivéve az igekötős igék, a névutós névszók és a tagadószó helytelen írását, mivel ilyen hiba esetén nem adható pont.

0 pont: a felsoroltaknál több és/vagy súlyosabb hiba esetén, vagy ha a szöveg nem éri el a 10 mondatot.

Ez az összesítés egyszerűen semmire sem használható, ami a helyesírás javítását illeti, igazából csak a javító magyartanárok tapasztalatára, rutinjára lehet számítani, más kérdés, hogy ezek vajon mennyire lennének egymással legalábbis alapvető lefedettségben. Erre vonatkozóan nincsenek ismereteim.

\section{6. Összegzés}

A tanulmány arra vállalkozott, hogy a középszintű magyarérettségi helyesírási javítókulcsát elemezze, és rámutasson azokra a problémákra, amelyek a helyesírási hibák javítását régóta jellemzik a középfokú oktatásban. A kritika alapvetően segítő szándékkal fogalmazódott meg: ideje lenne a középiskolai magyartanároknak és a helyesírási szakembereknek az együttműködésével átgondolni a fenti kérdéseket és kidolgozni egy olyan egységes javítási útmutatót, a rendszer és az úzus együttes figyelembevételével, amely alapot jelenthetne a felvételik és az érettségi javításában, és amely az életkori sajátosságoknak megfelelőn alakítható is lenne. Csak a közös gondolkodásban hiszek, csakis az lehet gyümölcsöző. Mindenesetre akármennyire is a pozitív attitűd jelenik meg ma már a pontozás során, mégis nagyon lényeges az egységes szempont- 
rendszer már csak azért is, mert a felvételiket és az emelt szintű érettségit olyan tanárok javítják, akik nem találkoztak a gyerekkel a korábbiakban. Ez még inkább szükségessé teszi az objektivizáltabb értékelés lehetőségét. A felvételi és az emelt szintű érettségi a továbbtanulást jelenti, az esélyegyenlőséget pedig az objektívabbá tett javítás is elősegítheti. A helyesírás tekintetében mindenképpen, hiszen ez egy sztenderdizációs kodifikáción alapuló, preskriptív és formalizálható rendszer, így minden további nélkül megalkotható egy sztenderdizált javítási útmutató is a jövőben.

\section{Irodalom}

AkH. ${ }^{12}=$ Magyar Tudományos Akadémia 2015. A magyar helyesírás szabályai. 12. kiadás. Akadémiai Kiadó. Budapest.

Antalné Szabó Ágnes 2008. A helyesírás kultúra fejlesztésének régi-új technikái. Anyanyelv-pedagógia 1/3-4: http://www.anyanyelv-pedagogia.hu/cikkek. php?id=109 (2020.07. 06.)

Bozsik Gabriella 1993. Az intézménynevek helyesírásának tanításáról. I. Magyartanítás 34/5: 29-32.

Bozsik Gabriella 1994. Az intézménynevek helyesírásának tanításáról. II. Magyartanítás 35/4: 31-34.

Bozsik Gabriella 1996. Helyesírási feladat- és mondatgyüjtemény. Student 2000. Eger.

Bozsik Gabriella 1998. Helyesírási feladatlapok a tudásszint felmérésére, ellenőrzésére. In: Bozsik Gabriella - Raisz Rózsa - Zimányi Árpád (szerk.): Helyesírásunkról, helyesírásunkért. Líceum Kiadó. Eger. 107-117.

Bozsik Gabriella 2000. Gondolatok a földrajzinév-írás tanításáról egy akadémiai kiadvány kapcsán. Magyartanítás 41/4: 32-34.

Bozsik Gabriella 2003. A helyesírás tanítása. In: Bozsik Gabriella - Dobóné Berencsi Margit - Zimányi Árpád: Anyanyelvi tantárgy-pedagógiánk vázlata. EKF Líceum Kiadó. Eger. 149-181.

Bozsik Gabriella 2004. Néhány földrajzinév-típus helyesírásának tanításáról. In:

Bozsik Gabriella - V. Raisz Rózsa (szerk.): Helyesírásunk időszerü kérdései a 21. század elején. EKF. Eger. 24-34.

Bozsik Gabriella 2007a. Módszertani javaslatok néhány tulajdonnévfajta helyesírásának tanításához. In: Bozsik Gabriella (szerk.): Két évtized a helyesírásért: A NagyJ. Béla országos helyesírási verseny előadásai és feladatai. EKF Líceum Kiadó. Eger. 163-175.

Bozsik Gabriella 2007b. A tulajdonnévírás módszertani eljárásai. Konferenciaelőadás. ELTE. Budapest.

Bozsik Gabriella 2007c. Helyesírási feladatlapok a tudásszint felmérésére, ellenőrzésére. In: Bozsik Gabriella - Eőry Vilma - V. Raisz Rózsa (szerk.): Hagyomány és újítás a helyesírásban. EKF Líceum Kiadó. Eger. 257-266.

Bozsik Gabriella 2009. Helyesírási gyakorlatgyüjtemény. Graféma 2000. Eger. 
Bozsik Gabriella 2011. A szóösszetételek helyesírásának tanítása. Konferenciaelőadás. II. Vályi András anyanyelv-pedagógiai konferencia. ELTE. Budapest. Bozsik Gabriella 2013. Módszertani eljárások és gyakorlatok a szóösszetételek helyesírásának tanításához. In: Paksi László - Györe Géza - Tóth-Márhoffer Márta - Bognárné Kocsis Judit (szerk.): Köszöntőkötet a 60 éves Zsolnai Józsefné Mátyási Mária tiszteletére. Pannon Kiadó. Veszprém. 23-28.

Bozsik Gabriella 2017. Jubileumi visszatekintés a Nagy J. Béla helyesírási verseny történetére. Anyanyelv-pedagógia 10/2: 87-94. http://www.anyanyelv-peda gogia.hu/cikkek.php?id=687 (2020. 07. 07.) https://doi.org/10.21030/anyp.2017. 2.11

Bozsik Gabriella 2019. Jubileumi visszatekintés a Nagy J. Béla helyesírási verseny történetére. In: Bozsik Gabriella - Ludányi Zsófia (szerk.): Szabályzat, oktatás, gyakorlat. Helyesírásról sokszínüen: A 2015-ös és a 2017-es Nagy J. Béla helyesírás verseny előadásai, feladatai és egyéb tanulmányok. Líceum Kiadó. Eger. 9-17. https://doi.org/10.21030/anyp.2017.2.11

Bősze Péter - Laczkó Krisztina 2009. Helyesírási meggondolások az orvosi nyelvben. In: Bősze Péter (szerk.): A magyar orvosi nyelv tankönyve. Medicina Kiadó. Budapest. 329-392.

Bősze Péter 2018. Magyar orvosi nyelv. Helyesírási útmutató. Medicina Kiadó. Budapest.

Elekfi László 2005-2007. Helyesírási hibák minősítése. In: Bozsik Gabriella (szerk.): Két évtized a helyesírásért. Líceum Kiadó. Eger. 176-181.

Fábián Pál 1986. A helyesírás iskoláinkban. In: Szende Aladár (szerk.): Program az anyanyelvi nevelés továbbfejlesztésére. Tankönyvkiadó. Budapest.

Fábián Pál 1993. Szaknyelvi helyesírási szabályzataink mérlege. Magyar Nyelvőr 117: 595-599.

Gráf Rezső - Fábián Pál - Szemere Gyula 1999. Helyesírásunk. Akadémiai Kiadó. Budapest.

Laczkó Krisztina 2016. A tulajdonnévi helyesírás változásai az AkH. 12. kiadásában. Névtani Értesítő 38: 181-191.

Laczkó Krisztina 2018. Körkép a magyar helyesírásról - áttekintés a 12. kiadás után. Magyar Nyelvőr 142: 136-149.

Laczkó Krisztina - Mártonfi Attila 2004. Helyesírás. Osiris Kiadó. Budapest.

Laczkó Krisztina - Mártonfi Attila 2008. Helyesírási tanácsadó. Osiris Kiadó. Budapest.

Ludányi Zsófia 2016. Szaknyelvi helyesírási változások az AkH.12 tükrében, különös tekintettel az orvosi nyelvre. Szaknyelv és Szakfordítás 16: 34-42.

Mártonfi Attila 2018. Tájékoztató bibliográfia "A helyesírás kézikönyvei" témában. Magyar Nyelvőr 142: 246-250.

Mártonfi Attila - Sólyom Jenő 2020. Fizikai helyesírási szótár. Megjelenés alatt.

Siptár Péter-Keszler Borbála-Tóth Etelka 2016. Kis magyar helyesírás. Akadémiai Kiadó. Budapest.

Tolcsvai Nagy Gábor 1998. A nyelvi norma. Akadémiai Kiadó. Budapest. 


\section{Internetes hivatkozások}

W1 - Magyar nyelv és irodalom. Középszintü írásbeli vizsga. Javitási-értékelési útmutató. Emberi Erőforrások Minisztériuma. 2020. http://dload.oktatas. educatio.hu/erettsegi/feladatok_2020tavasz_kozep/k_magyir_20maj_ut.pd $\mathrm{f}$ ?fbclid=IwAROIbcAD4dDCDBQsy-9SoddrqPSJitCjmMmsMYnf1dx0dzOKU3x qi2X2CtM (2020. 06. 01.)

W2 - A Wikipédia elrabolta Europát a csillagászoktól. https://index.hu/techtud/ 2020/06/02/a_wikipedia_elrabolta_europat_a_csillagaszoktol/?fbclid=IwA R3yUWuJnUf6ES9sooGnDaqGR6q9sTpvuka1Kb1q1oZBPMdHrp7t7QpAkHM (2020. 07. 05.)

W3 - Magyar nyelv a 4. évfolyamosok számára. Javitási-értékelési útmutató. 2020. január 18. https://www.oktatas.hu/pub_bin/dload/kozoktatas/beiskolazas/ feladatsorok/2020/AJ1_4.pdf (2020.07. 01.)

W4 - Magyar nyelv a 6. évfolyamosok számára. Javitási-értékelési útmutató. 2020. január 18. https://www.oktatas.hu/pub_bin/dload/kozoktatas/beiskolazas/ feladatsorok/2020/AJ1_6.pdf (2020.07. 05.)

W5 - Magyar nyelv a 8. évfolyamosok számára. Javitási-értékelési útmutató. 2020. január 18. https://www.oktatas.hu/pub_bin/dload/kozoktatas/beiskolazas/ feladatsorok/2020/AJ1_8.pdf (2020. 07. 05.) 